\title{
Telaah Input Data Sistem Informasi Kesehatan di Puskesmas Gondokusuman II Kota Yogyakarta
}

\author{
Angga Eko Pramono ${ }^{1}$, Nur Rokhman ${ }^{2}$, Nuryati $^{3}$ \\ Departemen Layanan dan Informasi Kesehatan, Sekolah Vokasi, Universitas Gadjah Mada 1,2,3 \\ anggaekopramono@ugm.ac.id ${ }^{1}$, nurrokhman@ugm.ac.id² ${ }^{2}$ nur3yati@ugm.ac.id ${ }^{3}$
}

\begin{abstract}
ABSTRAK
Latar Belakang: Saat ini, sistem informasi kesehatan diperlukan untuk mendukung layanan kesehatan. Penerapan sistem informasi kesehatan berpotensi meningkatkan performa fasilitas kesehatan, menghemat biaya, dan meningkatkan kepuasan pelanggan (pasien). Namun, implementasi banyak sistem justru akan menambah beban kerja petugas.

Tujuan: Penelitian ini bertujuan untuk mendeskripsikan penggunaan dan jenis-jenis data pada sistem informasi kesehatan di Puskesmas Gondokusuman II Kota Yogyakarta.

Metode: Penelitian ini merupakan penelitian kualitatif dengan pendekatan studi kasus. Subyek penelitian ini adalah lima orang petugas pengguna sistem sedangkan obyeknya adalah sistem informasi kesehatan yang diimplementasikan di puskesmas. Pengumpulan data dilakukan dengan cara observasi, wawancara mendalam, dan studi dokumentasi. Data yang terkumpul dianalisis menggunakan teknik analisis data kualitatif.

Hasil: Sistem informasi kesehatan yang digunakan di Puskesmas Gondokusuman II sebanyak tujuh sistem. Pengguna harus memasukkan data kesehatan yang sama pada setiap sistem informasi kesehatan. Data tersebut meliputi identitas sosial pasien dan data klinis. Proses pemasukan data yang sama akan membuat pekerjaan menjadi tidak efisien. Untuk mengatasinya, model pengembangan bridging system berbasis web service perlu dikembangkan.

Kesimpulan: Bridging system yang diterapkan sebaiknya mencakup semua sistem informasi kesehatan sehingga pengguna tidak perlu memasukkan data yang sama secara berulang. Sistem memungkinkan data yang sama secara otomatis masuk ke sistem lain tanpa harus diketikkan kembali.
\end{abstract}

Kata kunci: sistem informasi kesehatan; data kesehatan

\section{ABSTRACT}

Background : Today, a health information system is needed to support health services. Implementation of health information systems may improve the performance of health care facilities, save operational costs, and improve patient satisfaction. However, the implementation of many systems will increase the workload of staffs.

Objective : This study aimed to describe the usage and data items of health information systems at Gondokusuman II Primary Health Center.

Methods : A qualitative research with case study approach was done. The subjects of this study were five staffs who use the health information systems and the object was health information systems. This research used observation, in-depth interview, and documentation study to collect its data. This study used qualitative analysis data technique.

Results : Health information system that is used in Gondokusuman II Primary Health Center as much as seven systems. This causes the user must enter the same healthcare data on each health information system. They are including the patient's social identity and clinical data. The same data entry process makes the job become inefficient. To overcome such problem, a bridging system model based on web service technology need to be developed.

Conclusion : Bridging systems should be able to include all of the health information systems so that users do not need to entry the same data repeatedly. Bridging system allows the same data to be automatically entered into another system without having to be re-inputed.

Keywords : health information system; healthcare data 


\section{PENDAHULUAN}

Penggunaan sistem informasi kesehatan berpotensi meningkatkan performa fasilitas kesehatan, menghemat biaya operasional, dan meningkatkan kepuasan pelanggan/pasien (Goldwzweig et al., 2009). Manajemen informasi kesehatan berfokus pada pelayanan kesehatan dan sumber informasi kesehatan guna menghasilkan informasi untuk kelangsungan dan kemajuan pelayanan kesehatan. Untuk itu, penanggung jawab manajemen informasi kesehatan harus mengumpulkan, mengolah, menganalisis, dan menyajikan data pelayanan kesehatan bagi kepentingan penelitian, pendidikan, perencanaan, dan evaluasi pelayanan kesehatan secara komprehensif dan terintegrasi.

Menurut Health Metrics Network (2008), sistem informasi kesehatan membutuhkan enam komponen yang saling berinteraksi satu sama lain untuk menghasilkan informasi yang lebih baik. Komponen tersebut adalah: 1) sumber daya sistem informasi kesehatan, yang meliputi sistem koordinasi dan kepemimpinan, kebijakan, finansial, sumber daya manusia, dan infrastruktur (sarana dan prasarana pendukung); 2) indikator-indikator yang merupakan domain utama informasi kesehatan, meliputi determinan kesehatan, sistem kesehatan, dan status kesehatan; 3) sumber data kesehatan; 4) manajemen data, yang meliputi penyimpanan, penjaminan kualitas, dan pemrosesan data; 5) proses perubahan data menjadi informasi; dan 6) penyebaran dan pemanfaatan informasi yang dapat digunakan untuk mendukung proses pengambilan keputusan.

Teknologi informasi yang terus berkembang mendorong dinas kesehatan di berbagai daerah di Indonesia untuk melakukan pengembangan dan pengelolaan sistem informasi masingmasing. Oleh sebab itu, masing-masing pemerintah daerah berupaya mengembangkan sistem informasi yang dapat mendukung proses pengumpulan dan pengolahan data di daerahnya (Pusat Data dan Informasi, 2011).
Proses pengelolaan data/informasi kesehatan memerlukan standar tertentu. Standar data/informasi di Indonesia masih belum memadai. Hal ini juga diperparah dengan akses dan sumber daya kesehatan yang tidak merata. Akibatnya, setiap fasilitas kesehatan mulai mengembangkan dan menerapkan sistem informasi menurut kemampuan dan kebutuhan masing-masing. Hal ini membuat sistem informasi dan teknologi informasi yang dipakai berbeda-beda dan sulit untuk dikomunikasikan. Selain itu, kepemilikan dan keamanan data yang dipertukarkan menjadi penghalang untuk penyediaan data yang bisa diakses oleh stakeholder terkait (Pusat Data dan Informasi, 2011).

Puskesmas sebagai salah satu fasilitas kesehatan di Indonesia dituntut untuk memberikan pelayanan kesehatan yang cepat, tepat, dan akurat. Oleh karena itu, puskesmas harus memanfaatkan kemajuan ilmu pengetahuan dan teknologi di bidang kesehatan untuk memenuhi tuntutan tersebut. Menurut Hatta (2013), negara anggota World Summit on the Information Society (WSIS) termasuk Indonesia harus mencapai target yaitu seluruh pusat kesehatan termasuk puskesmas serta rumah sakit sudah terhubungkan dengan teknologi informasi dan komunikasi pada tahun 2015. Hal ini tentunya menjadi tantangan tersendiri bagi Indonesia mengingat kondisi geografis yang berbeda-beda dan sebaran populasi penduduk yang tidak merata.

Puskesmas di wilayah Kota Yogyakarta telah menerapkan sistem informasi kesehatan sejak tahun 2005 sebagai salah satu komponen pendukung paradigma sehat di dalam bidang pembangunan kesehatan. Sistem informasi kesehatan yang digunakan beragam, meliputi: 1) sistem informasi manajemen puskesmas (SIMPUS), 2) sistem informasi tuberculosis terpadu (SITT), 3) software BPJS on line, 4) sistem informasi manajemen imunisasi terpadu (SIMUNDU), 5) software PWS KIA (KARTINI), dan 6) sistem informasi HIV/AIDS (SIHA), serta 7) sistem informasi gizi (SIGIZI). 
Hasil penelitian McAlearney et al. (2010) menunjukkan bahwa penerapan sistem informasi kesehatan baru akan menambah alur kerja baru dan menghasilkan lebih banyak pekerjaan. Pengguna harus meng-entry data beberapa kali di setiap sistem informasi kesehatan yang berbeda. Selain itu, kegiatan tambahan lainnya juga bertambah seperti mengecek validitas data dan entry data secara manual ke dalam sistem informasi kesehatan ketika data tidak berhasil di di-import. Demikian halnya di puskesmas, dengan semakin banyaknya sistem informasi yang diterapkan, setiap petugas harus memasukkan data ke masing-masing sistem informasi kesehatan tersebut. Artinya, pekerjaan petugas bertambah. Hal ini beresiko pula terhadap kemungkinan duplikasi dan ketidakvalidan data dan informasi yang dihasilkan.

Informasi pelayanan kesehatan yang bermutu dan terintegrasi dengan baik dan benar biasanya bersumber dari data klinis yang terdokumentasi dengan baik di dalam rekam medis. Berkembangnya rekam medis elektronik, dimana setiap entry data secara langsung menjadi masukan (input) dari sistem/manajemen informasi kesehatan akan mendukung proses pendokumentasian data klinis yang bersumber dari rekam medis. Peraturan Menteri Kesehatan RI Nomor 269/Menkes/Per/III/2008 tentang Rekam Medis telah menjelaskan bahwa fungsi rekam medis sangat vital dan kompleks. Fungsi rekam medis adalah dalam bidang pemeliharaan kesehatan dan pengobatan pasien, alat bukti dalam proses penegakan hukum, disiplin dan penegakan etika kedokteran/kedokteran gigi, keperluan pendidikan dan penelitian, dasar pembiayaan pelayanan kesehatan, dan sumber data statistik dan pelaporan kesehatan. Untuk dapat memenuhi fungsi tersebut dengan optimal, pengisian data pada sistem informasi kesehatan harus lengkap.

Penelitian ini bertujuan untuk mengevaluasi implemetasi dari sistem informasi kesehatan di Puskesmas Gondokusuman II Kota Yogyakarta.

\section{METODE}

Penelitian ini merupakan penelitian kualitatif dengan pendekatan studi kasus di Puskesmas Gondokusuman II Kota Yogyakarta. Penelitian dilaksanakan mulai bulan Juni hingga Oktober 2017. Subyek penelitian ini adalah lima orang petugas yang menggunakan sistem informasi kesehatan yaitu 1 orang tenaga rekam medis, 1 orang bidan, 2 orang perawat, dan 1 orang nutrisionis. Obyek pada penelitian ini adalah sistem informasi kesehatan di puskesmas.

Pengumpulan data menggunakan teknik observasi, wawancara mendalam, dan studi dokumentasi. Observasi dilakukan dengan mengamati secara langsung kinerja aplikasi sistem informasi kesehatan dan kinerja petugas saat menggunakan sistem. Wawancara secara mendalam dilakukan terhadap subyek penelitian terkait penggunaan sistem informasi kesehatan dan jenis data yang diinputkan. Studi dokumentasi dilakukan dengan melihat laporan yang dihasilkan oleh aplikasi sistem. Triangulasi teknik digunakan untuk menjamin keabsahan data.

Data yang diperoleh dalam penelitian ini merupakan data kualitatif. Dengan demikian, teknik analisis data yang digunakan adalah teknik analisis data kualitatif. Langkah-langkah dalam menganalisis data kualitatif menurut Sugiyono (2013) sebagai berikut:

1. Reduksi Data

Reduksi data merupakan proses pemilahan data penelitian. Reduksi data merupakan suatu bentuk analisis yang bertujuan untuk menajamkan, mengelompokkan, mengarahkan, membuang yang tidak perlu, dan mengkoordinasi data satu dengan data yang lain dengan cara sedemikian rupa sehingga kesimpulan akhirnya dapat ditarik dan diverifikasi (Moleong, 2008).

2. Penyajian Data

Penyajian data adalah proses menampilkan data penelitian. Penelitian kualitatif umumnya menyajikan data dalam format teks yang bersifat naratif. Penyajian seperti itu dapat memberikan informasi yang detail dan menyeluruh. Selain itu, penyajian data juga dilakukan 
dengan cara menampilkan gambar dan tabel pendukung untuk memperjelas maksud penelitian.

3. Menarik kesimpulan/verifikasi

Langkah terakhir dari analisis data kualitatif adalah penarikan kesimpulan/ verifikasi. Kesimpulan yang disebutkan didukung oleh bukti-bukti yang valid dan relevan saat peneliti mengumpulkan data di lapangan sehingga merupakan kesimpulan akhir penelitian yang dapat dipertanggungjawabkan keabsahannya.

\section{HASIL DAN PEMBAHASAN}

Manajemen data di Puskesmas Gondokusuman II Kota Yogyakarta diolah secara manual maupun komputerisasi. Sistem informasi kesehatan yang digunakan dalam manajemen data di Puskesmas Gondokusuman II antara lain adalah sistem informasi manajemen puskesmas (SIMPUS), sistem informasi gizi (SIGIZI), sistem informasi imunisasi terpadu (SIMUNDU), sistem informasi HIV/AIDS (SIHA), sistem informasi tuberkulosis terpadu (SITT), software PWS KIA (KARTINI) dan sistem informasi BPJS on line ( $\mathrm{p}$-Care).

1. Sistem Informasi Manajemen Puskesmas (SIMPUS)

Sistem Informasi Puskesmas (SIMPUS) merupakan suatu sistem informasi yang dirancang secara khusus untuk dapat dimanfaatkan di puskesmas. Puskesmas sebagai salah satu jenis fasilitas kesehatan memiliki kebutuhan yang unik, dan berbeda dengan fasilitas kesehatan lainnya. Program sistem informasi manajemen puskesmas di Puskesmas Gondokusuman II dilaksanakan di bagian pendaftaran, balai pengobatan umum, balai pengobatan gigi, dan kesehatan ibu anak. bagian konsultasi gigi, konsultasi psikologi, laboratorium, sanitarian/kesehatan lingkungan, dan bagian penyuluh kesehatan masyarakat belum melaksanakan program SIMPUS.

Sistem Informasi Manajemen Puskesmas (SIMPUS) di Puskesmas Gondokusuman II diakses atau digunakan oleh seluruh petugas yang memberikan pelayanan kepada pasien. Masing-masing bagian atau ruangan memiliki penanggung jawab sendiri. Kualifikasi dari penanggung jawab bagian dalam mengakses sistem informasi manajemen puskesmas (SIMPUS) adalah petugas yang memiliki kemampuan dalam mengoperasikan komputer. Tampilan utama SIMPUS tersaji pada Gambar 1.

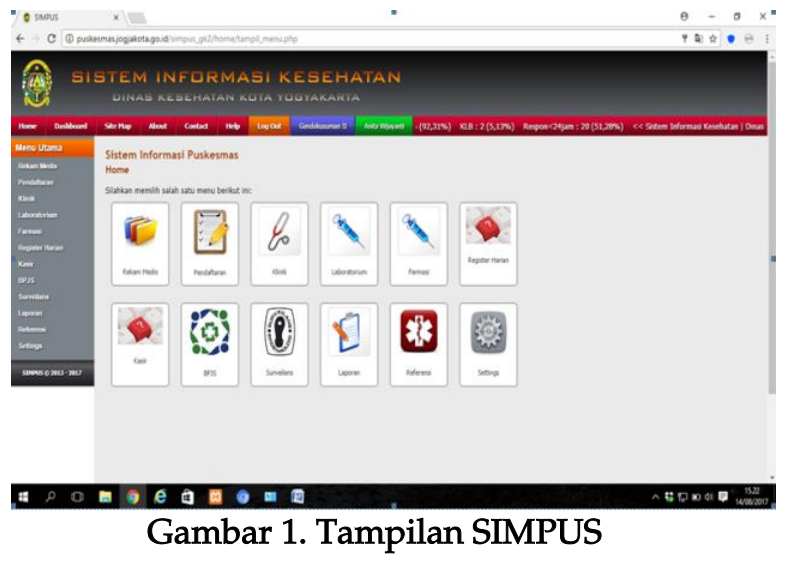

Setiap hari kerja, petugas harus memasukkan data kunjungan pasien ke dalam SIMPUS. Data yang harus dimasukkan oleh petugas ke dalam SIMPUS terdiri dari data sosial dan data medis pasien. Data sosial meliputi: nomor rekam medis, nama lengkap pasien, tanggal lahir, tempat lahir, jenis kelamin, golongan darah, alamat, nomor KTP/NIK, nomor telepon, nomor $\mathrm{KK} / \mathrm{C} 1$, dan nomor jaminan sosial. Data medis meliputi tanggal registrasi/pendaftaran, disabilitas, anamnesis, pemeriksaan fisik (berat badan, tinggi badan), diagnosis, kode diagnosis, pemeriksaan laboratorium, dan obat. Kutipan hasil wawancara terhadap petugas tersaji pada Tabel 1 .

2. Sistem informasi HIV / AIDS (SIHA)

Sistem Informasi HIV/AIDs (SIHA) adalah sistem yang digunakan untuk pencatatan, pengolahan data, dan pelaporan terkait data IMS (Infeksi Menular Seksual), VCT (Voluntary Counseling test), PITC (Provider Initiated Testing and Counselling), metadhon, dan data HIV/AIDS. Pengguna SIHA antara lain adalah Tim Klinik IMS/PITC/VCT terutama petugas RR (Recording and Reporting).

Petugas memasukkan data hasil pemeriksaan dan pengobatan pasien terkait kasus HIV/AIDS ke dalam SIHA. Data yang harus dimasukkan oleh petugas ke dalam SIHA terdiri dari data sosial dan 
data medis pasien. Data sosial meliputi: nomor rekam medis, nama lengkap pasien, tanggal lahir, tempat lahir, jenis kelamin, alamat, nomor identitas pribadi (KTP), dan nomor telepon. Data medis meliputi tanggal registrasi/ pendaftaran, anamnesis, pemeriksaan fisik, diagnosis, kode diagnosis, pemeriksaan laboratorium, dan obat. Tampilan SIHA tersaji pada Gambar 2.

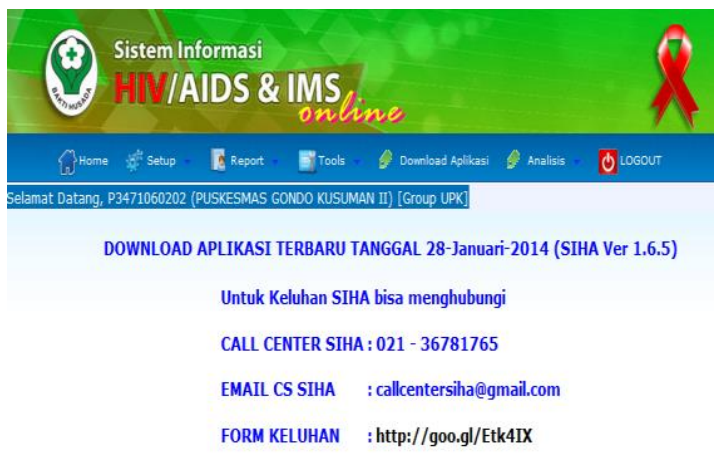

Gambar 2. Tampilan SIHA

3. SITT (Sistem Informasi Tuberculosis Terpadu)

Sistem Informasi Tuberculosis Terpadu (SITT) adalah sistem yang digunakan untuk pencatatan, pengolahan data, dan pelaporan terkait data tuberculosis. Pengguna SITT adalah pemegang program TB yaitu seorang perawat.

Perawat memasukkan data hasil pemeriksaan dan pengobatan pasien terkait kasus tuberkulosis ke dalam SITT. Data yang harus dimasukkan oleh petugas ke dalam SITT terdiri dari data sosial dan data medis pasien. Data sosial meliputi: nomor rekam medis, nama lengkap pasien, tanggal lahir, tempat lahir, jenis kelamin, alamat, nomor identitas pribadi (KTP), dan nomor telepon. Data medis meliputi tanggal registrasi/ pendaftaran, anamnesis, pemeriksaan fisik, diagnosis, kode diagnosis, pemeriksaan laboratorium, dan obat. Tampilan SITT tersaji pada Gambar 3.

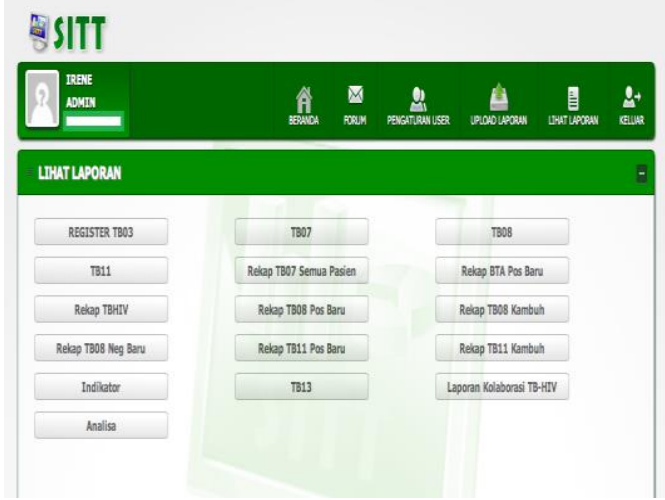

Gambar 3. Tampilan SITT

4. SIMUNDU (Sistem Informasi Imunisasi Terpadu)

Sistem Informasi Imunisasi Terpadu (SIMUNDU) adalah sistem yang digunakan untuk pencatatan, pengolahan data, dan pelaporan terkait imunisasi di Puskesmas. Pengguna SIMUNDU adalah bidan.

Bidan memasukkan data hasil pemeriksaan dan pengobatan pasien terkait kegiatan imunisasi ke dalam SIMUNDU. Data yang harus dimasukkan oleh petugas ke dalam SIMUNDU terdiri dari data sosial dan data medis pasien. Data sosial meliputi: nomor buku, nomor rekam medis, nama lengkap pasien, nama orang tua, tanggal lahir, tempat lahir, jenis kelamin, dan alamat. Data medis meliputi tanggal registrasi/pendaftaran, data vaksin (jenis dan dosis vaksin), data pascaimunisasi (gejala dan keterangan), dan obat. Tampilan SIMUNDU tersaji pada Gambar 4.

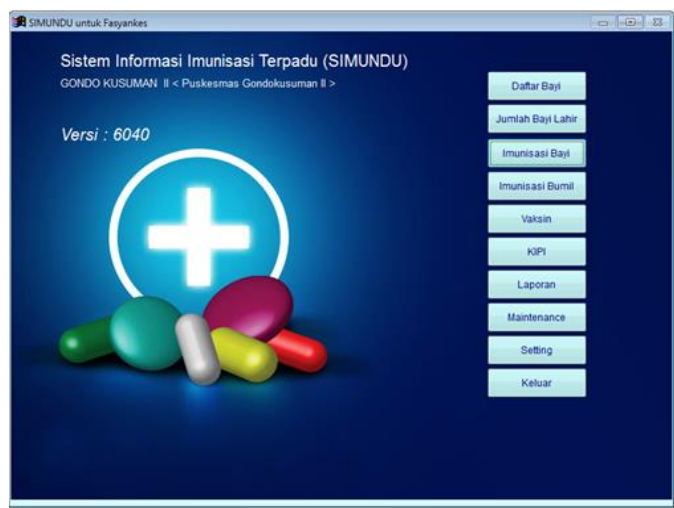

Gambar 4. Tampilan SIMUNDU

\section{Software PWS KIA "Kartini"}

Software PWS KIA "Kartini" adalah sistem informasi untuk pencatatan, pengolahan data, dan pelaporan terkait pemantauan wilayah setempat terkait 
kesehatan ibu dan anak. Pengguna sistem ini adalah bidan.

Bidan memasukkan data hasil pemeriksaan dan pengobatan pasien terkait kasus kehamilan, persalinan, dan bayi baru lahir ke dalam Kartini. Data yang harus dimasukkan oleh petugas terdiri dari data sosial dan data medis pasien. Data sosial meliputi: nomor identitas (KK/KTP), nama ibu, nama suami, nama bayi, tanggal lahir, tempat lahir, jenis kelamin, golongan darah, alamat, dan nomor telepon.

Data medis dibagi lagi menjadi dua kelompok. Kelompok pertama terkait data medis ibu hamil, meliputi: tanggal registrasi/pendaftaran, data pemeriksaan fisik (berat badan, tinggi badan, tinggi fundus uteri (TFU)), data bayi (posisi bayi, presentasi bayi), data konseling, hasil pemeriksaan laboratorium, data screening dan suntik, dan obat. Kelompok kedua merupakan data ibu melahirkan, meliputi: tanggal bersalin, keadaan bayi (berat badan, jenis kelamin, panjang badan, dan kondisi lahir), keadaan ibu, data komplikasi, presentasi bayi, tempat bersalin, cara persalinan, dan data penolong persalinan. Tampilan software "Kartini "tersaji pada Gambar 5.

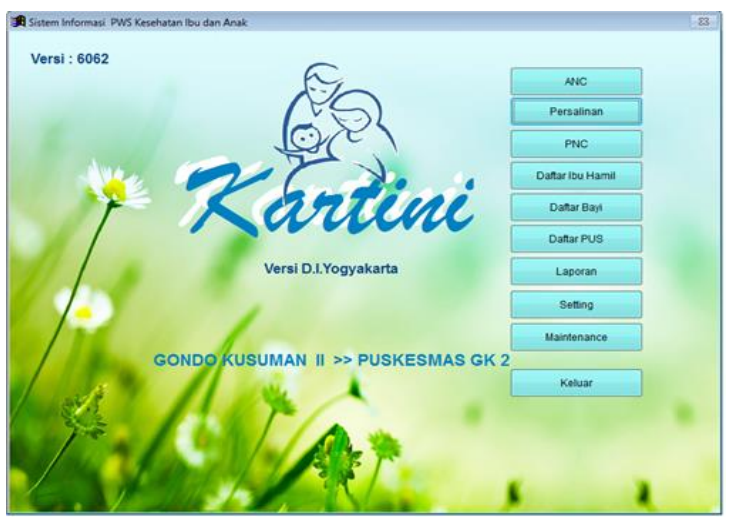

Gambar 5. Tampilan "Kartini"

\section{SIGIZI (Sistem Informasi Gizi)}

Sistem Informasi Gizi (SIGIZI) adalah sistem informasi untuk pencatatan, pengolahan data, dan pelaporan terkait data peningkatan status gizi masyarakat di wilayah kerja puskesmas. Pengguna SIGIZI adalah petugas nutrisionis.

Nutrisionis memasukkan data pelayanan gizi masyarakat ke dalam SIGIZI. Data yang harus dimasukkan oleh petugas terdiri dari data sosial dan data medis pasien. Data sosial meliputi: nomor identitas, nama lengkap, tanggal lahir, tempat lahir, jenis kelamin, dan alamat. Data medis meliputi tanggal pelayanan, status pasien, data pelayanan gizi, dan konsultasi gizi. Tampilan SIGIZI tersaji pada Gambar 6.

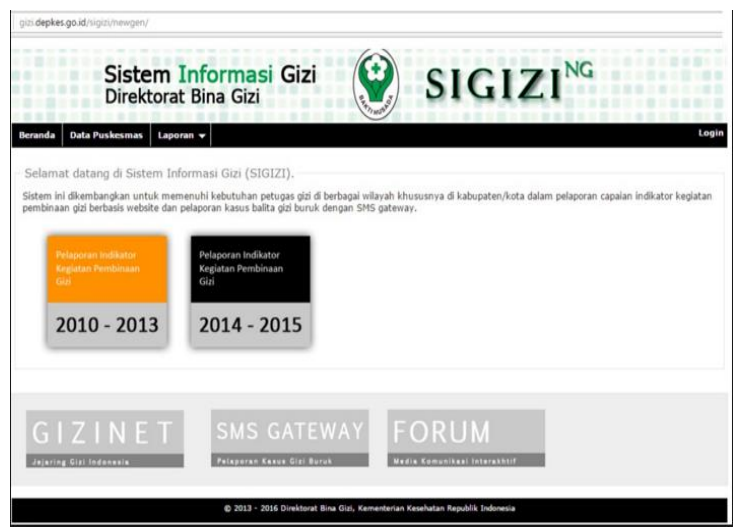

Gambar 6. Tampilan SIGIZI

\section{P-Care (Sistem Informasi JKN)}

Aplikasi P-Care atau primary care merupakan sistem informasi yang digunakan untuk mendukung pelayanan kesehatan pada pasien anggota BPJS (Badan Penyelenggara Jaminan Sosial) Kesehatan. Sistem informasi ini berbasis komputer dan bersifat online. Aplikasi ini diakses oleh seluruh petugas yang memberikan pelayanan kepada pasien. Masing-masing bagian atau ruangan memiliki penanggung jawab sendiri.

Petugas memasukkan data pasien yang terdaftar di BPJS Kesehatan ke dalam P-Care. Data yang harus dimasukkan oleh petugas ke dalam SIMPUS terdiri dari data sosial dan data medis pasien. Data sosial meliputi: nomor kartu/peserta, nomor identitas (KTP), nama lengkap, status kepesertaan, jenis peserta, tanggal lahir, usia, jenis kelamin, alamat, dan nama PPK (pemberi pelayanan kesehatan). Data medis meliputi tanggal registrasi/pendaftaran, jenis kunjungan, jenis rawatan, poliklinik tujuan, pemeriksaan fisik (berat dan tinggi badan, tekanan darah, respiratory rate, dan heart rate), diagnosis, kode diagnosis, pemeriksaan laboratorium, dan obat. Tampilan P-Care tersaji pada Gambar 7. 


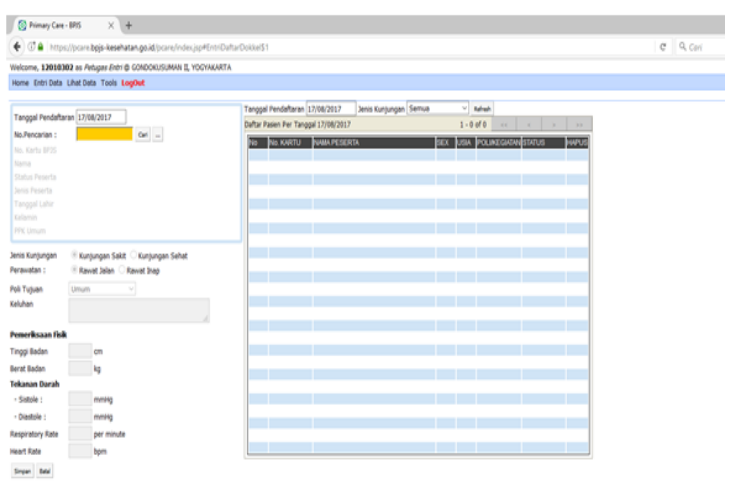

Gambar 7. Tampilan P-Care

Berdasarkan data tersebut dan hasil wawancara yang dilakukan kepada responden, ada beberapa item data yang sama dan harus dimasukkan petugas ke dalam setiap sistem informasi kesehatan. Data yang sama disajikan pada Tabel 2.

Tabel 2. Data Antar-SIK yang Sama

\begin{tabular}{ll} 
Data Sosial & \multicolumn{1}{c}{ Data Medis } \\
\hline Nama & Tanggal \\
pasien & registrasi/kunjungan \\
Nomor & Klinik/bagian \\
identitas & \\
Tanggal & Pemeriksaan fisik \\
lahir & \\
Umur & Pemeriksaan laboratorium \\
Jenis & Diagnosis \\
kelamin & \\
Alamat & Terapi/obat \\
- & Nama tenaga kesehatan \\
\hline
\end{tabular}

Tabel 1. Rangkuman Hasil Wawancara Responden

\section{Responden \\ ke- \\ Kutipan Wawancara}

1 Data yang di-entry ke SIMPUS banyak banget sih...ada data sosial dan data medis. Data sosial itu ada nomor RM, nama lengkap pasien, TTL, jenis kelamin, golongan darah, alamat, nomor KTP, nomor telepon, nomor KK/C1, dan nomor jaminan sosial sedangkan data medis isinya tuh tanggal registrasi, disabilitas, anamnesis, pemeriksaan fisik, diagnosis, kode diagnosis, pemeriksaan laboratorium, dan obat.

Untuk P-Care, datanya hampir sama kayak di SIMPUS tapi nggak sebanyak SIMPUS...ada data sosial meliputi nomor kartu peserta, nomor identitas, nama lengkap, status dan jenis peserta, tanggal lahir, usia, jenis kelamin, alamat, dan nama PPK. Data medisnya yaitu tanggal pendaftaran, jenis kunjungan, jenis rawatan, poliklinik tujuan, pemeriksaan fisik (berat dan tinggi badan, tekanan darah, respiratory rate, dan heart rate), diagnosis dan kodenya, hasil lab, dan obat.

2 Data yang dimasukkan ke SIHA ada macem-macem, ada data diri pasien, contohnya nomor RM, nama, TTL, jenis kelamin, alamat, nomor identitas, dan telepon. Lainnya itu ada data medis...isinya tanggal registrasi, hasil anamnesis dan pemeriksaan fisik, diagnosis, kode diagnosis, pemeriksaan lab, dan pemberian obat.

3 yang diinputkan banyak mas, ada data sosialnya pasien yaitu nomor RM, nama pasien, TTL, jenis kelamin, alamat, nomor KTP, dan nomor telepon...kalo data medisnya yaa tanggal registrasi, anamnesis, pemeriksaan fisik, diagnosis, kode diagnosis, pemeriksaan laboratorium, dan obat.

4 SIMUNDU tentu saja isinya data pelayanan imunisasi, mas...ada data sosial yang berisi nomor buku, nomor rekam medis, nama lengkap bayi, nama orang tua, tanggal lahir, tempat lahir, jenis kelamin, dan alamat. Kalo data medis yaa berisi tanggal registrasi, jenis vaksin, dosis vaksin, data pascaimunisasi, dan obat lain yang diberikan bila perlu.

Data sosial di Kartini isinya tuh ada nomor identitas, bisa pake KK ato KTP, nama ibu, nama suami, nama bayi, TTL ibu, jenis kelamin, golongan darah, alamat, dan telepon. Kalo data medis dibagi jadi dua kelompok utama. Kelompok data pertama untuk ibu hamil, isinya tanggal registrasi ato pendaftaran, data pemeriksaan fisik yang berisi data berat badan, tinggi badan, tinggi fundus uteri, data bayi yang berisi posisi bayi dan presentasi bayi, data konseling, hasil pemeriksaan lab, data screening dan suntik, serta data obat. Kelompok berikutnya tuh isinya data-data saat si ibu melahirkan....ada tanggal bersalin, keadaan bayi, keadaan ibu, data komplikasi, presentasi bayi, tempat 
Tabel 1. (lanjutan) Rangkuman Hasil Wawancara Responden

\begin{tabular}{cl}
$\begin{array}{c}\text { Responden } \\
\text { ke- }\end{array}$ & \multicolumn{1}{c}{ Kutipan Wawancara } \\
\hline 4 & $\begin{array}{l}\text { bersalin, cara persalinan, dan data penolong persalinan...lumayan banyak } \\
\text { datanya mas, hehehe }\end{array}$ \\
5 & $\begin{array}{l}\text { Di SIGIZI ini ada data sosial pasien, Pak...isinya nomor identitas, nama lengkap, } \\
\text { tanggal lahir, tempat lahir, jenis kelamin, dan alamat. Selain itu saya juga entry } \\
\text { data medis, isinya tanggal pelayanan, status pasien, data pelayanan gizi, dan } \\
\text { konsultasi gizi. }\end{array}$ \\
\hline
\end{tabular}

Peraturan Menteri Kesehatan RI Nomor 269/Menkes/Per/III/2008 tentang Rekam Medis telah menyebutkan bahwa fungsi rekam medis adalah pemeliharaan kesehatan dan pengobatan pasien, alat bukti dalam proses penegakan hukum, disiplin kedokteran dan kedokteran gigi, penegakan etika kedokteran dan etika kedokteran gigi, keperluan pendidikan dan penelitian, dasar pembayaran biaya pelayanan kesehatan, serta data statistik kesehatan. Untuk dapat memenuhi fungsi tersebut dengan optimal, pengisian data pada sistem informasi kesehatan harus lengkap.

Masalah yang terjadi di fasilitas pelayanan kesehatan tingkat pertama adalah adanya double entry pada p-Care dan pada software yang telah dimiliki masing-masing sarana pelayanan kesehatan tingkat pertama sehingga menambah beban kerja (Sudarti, 2015). Hal ini juga menjadi tantangan yang dihadapi oleh petugas di Puskesmas Gondokusuman II Kota Yogyakarta. Petugas harus memasukkan data pelayanan kepada pasien pada masingmasing sistem. Sebenarnya, sebagian sistem mempunyai data yang unik dan user yang berbeda. Namun, beberapa item data pada setiap sistem sama. Hal ini menyebabkan petugas harus memasukkan data yang sama. Artinya, pekerjaan yang dilakukan oleh petugas bertambah. Seringkali, hal ini juga berpengaruh pada kelengkapan pengisian data (Weiskopf et al., 2013; Wright et al., 2015).

Hasil penelitian Rokhman et al. (2016) menunjukkan bahwa sistem informasi manajemen puskesmas (SIMPUS) sudah dibuat agar dapat mengakses data BPJS melalui teknologi web service yang telah disiapkan infrastrukturnya oleh BPJS. Mekanisme integrasi atau bridging data dapat dilihat pada Gambar 8.

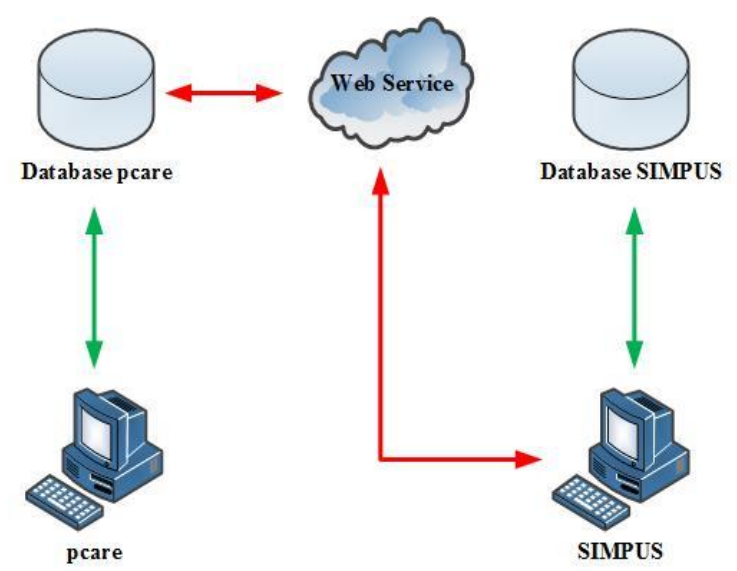

Gambar 8. Skema Bridging System

Berdasarkan skema pada Gambar 8, bridging system seharusnya dapat dikembangkan lebih lanjut secara lebih komprehensif. Pengembangan bridging system diharapkan dapat melingkupi seluruh sistem informasi kesehatan yang diimplementasikan. Adapun rencana skema pengembangannya dapat dilihat pada Gambar 9.

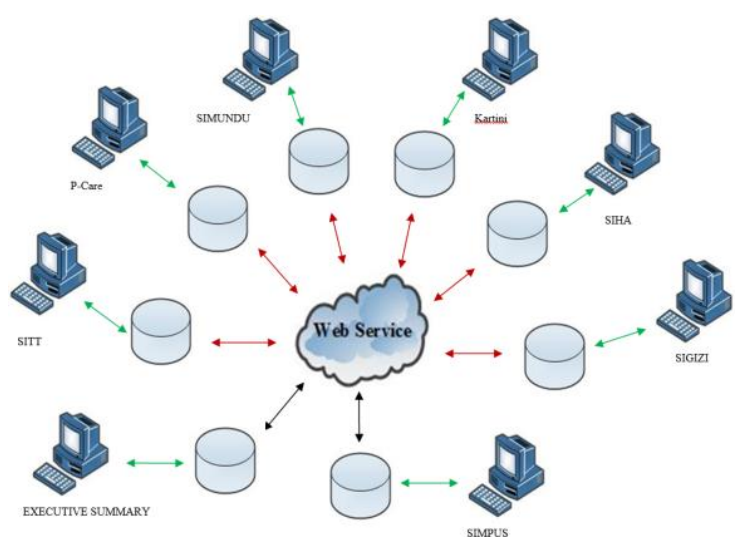

Gambar 9. Skema Pengembangan Bridging System

Skema tersebut memungkinkan komunikasi antar-sistem informasi kesehatan sehingga petugas tidak perlu memasukkan data yang sama secara 
berulang-ulang. Pun demikian untuk berbagai sistem informasi kesehatan yang digunakan saat ini. Konsep implementasi teknologi web service adalah adanya interaksi antara service provider dan service requester (Kreger, 2003). Dengan menggunakan teknologi web service ini, data yang diinputkan di SIMPUS juga akan terinput di basis data sistem informasi lainnya secara otomatis.

\section{PENUTUP}

Penggunaan sistem informasi kesehatan di Puskesmas Gondokusuman II Kota Yogyakarta yang beragam menyebabkan petugas harus memasukkan data yang sama sehingga menambah beban kerja. Data tersebut meliputi data sosial dan data medis. Agar dapat mengurangi beban kerja petugas terkait double entry data, penerapan bridging system data kesehatan menggunakan teknologi web services sangat diperlukan. Dengan menggunakan teknologi web service ini, data yang diinputkan di salah satu sistem informasi kesehatan juga akan secara tidak langsung juga akan otomatis terinput di basis data sistem informasi lainnya.

\section{DAFTAR PUSTAKA}

Goldzweig, C. L., Towfigh, A., Maglione, M., \& Shekelle, P. G. (2009). Costs and benefits of health information technology: new trends from the literature. Health Affairs (Project Hope), 28, 282-93.

Hatta, G. R. (2013). Pedoman Manajemen Informasi Kesehatan di Sarana Pelayanan Kesehatan, Edisi Revisi. Jakarta: UI-Press.

Health Metrics Network. (2008). Assessing the national health information system an assessment tool. Health San Francisco, 1-73.

Kreger, H. (2003). Fulfilling the web services promise. Communication of The ACM, 46 (6), 29-34.
McAlearney, A. S., Robbins, J., Hirsch, A., Jorina, M., \& Harrop, J. P. (2010). Perceived efficiency impacts following electronic health record implementation: an exploratory study of an urban community health center network. International Journal of Medical Informatics, 79 (12), 807-16.

Moleong, L. J. (2008). Metodologi Penelitian Kualitatif. Bandung: Remaja Rosdakarya.

Pusat Data dan Informasi. (2011). SIKDA Generik. Buletin Jendela Data dan Informasi, (3), 1-8.

Rokhman, N., Nuryati, \& Pramono, A. E. (2016). Implementasi bridging system di Puskesmas Gondokusuman 2 Kota Yogyakarta. Prosiding Seminar Nasional Teknologi Terapan 2016, (2), 89-95.

Sudarti, R. (2015). Evaluasi implementasi perangkat lunak p-care di Puskesmas Kotagede I Kota Yogyakarta menggunakan metode Technology Acceptance Model (TAM). Tugas Akhir. Yogyakarta: Universitas Gadjah Mada.

Sugiyono. (2013). Metode Penelitian Kuantitatif, Kualitatif, dan $R \& D$. Bandung: Alfabeta.

Weiskopf, N. G., Hripcsak, G., Swaminathan, S., \& Weng, C. (2013). Defining and measuring completeness of electronic health record for secondary use. Journal of Biomedical Informatics, 46, 830-836.

Wright, A., McCoy, A. B., Hickman, T. T., Hilaire, D. S., Borbolla, D., Bowes III, W. A., Dixon, W. G., Dorr, D. A., Krall, M., Malholtra, S., Bates D. W., \& Sittig, D.F. (2015). Problem list completeness in electronic health records: A multi-site study and assessment of success factors. International Journal of Medical Informatics, 84, 784-790. 